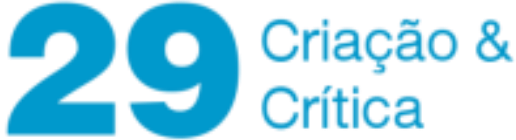

\section{QUEM É MULHER DE VERDADE? - CORPO FEMININO E SEXUALIDADE EM A VIA CRUCIS DO CORPO, DE CLARISSE LISPECTOR}

\author{
Ana Paula Comissário \\ Rosanne Bezerra de Araújo²
}

Resumo: O presente trabalho pretende investigar de que modo o corpo feminino e a sexualidade se configuram nos contos Ele me bebeu e Praça mauá do livro A via crucis do corpo (1991), de Clarice Lispector (1920- 1977). Nessa coletânea de contos, o corpo feminino adquire contornos mais complexos ao vir atravessado por questões, como travestilidade e condição feminina. Tentaremos analisar como os discursos de gênero e sexualidade operam na formação identitária das personagens, reafirmando ou negando concepções hegemônicas do que vem a ser mulher. Como aporte teórico, adotamos a crítica literária feminista (ZOLIN, 2009), a noção de abjeto e performatividade de gênero de Butler (2003), e as contribuições sobre corpo, erotismo e sexualidade de Foucault (2015) e Paz (1994). As análises dos contos apontam para o caráter ficcional das categorias de sexo e gênero, na medida em que um sexo (corpo biologicamente diferenciado), sem o gênero que the atribui culturalmente um significado, é um corpo vazio. Assim, se não são naturais, propomos a sua subversão, como fazem até certo ponto as personagens das narrativas, adotando performatividades que cruzem as fronteiras binárias em direção à libertação dos corpos e suas potencialidades.

PALAVRAS-CHAVE: Clarice Lispector; Literatura; Corpo feminino; Sexualidade; Erotismo.

\section{WHO IS A REAL WOMAN? - FEMALE BODY AND SEXUALITY ON THE VIA CRUCIS OF THE BODY, BY CLARICE LISPECTOR}

ABSTRACT: This work aims at investigating how the female body and sexuality is portrayed in the short stories He drank me up and Mauá square from the book The via crucis of the body (1991), by Clarice Lispector (1920-1977). Her book depicts a more complex outline of the female body, marked by sexuality and aging issues. We propose an analysis of how gender and sexuality discourses might affect character identity formation, strengthening or discouraging the hegemonic concepts of what it is to be a woman. This analysis is grounded on the feminist literary criticism (ZOLIN, 2009), on Butler's (2003) notion of abject and performativity, and on Foucault's (2015) and Paz's (1994) contributions on body, eroticism, and sexuality. The analyses of the short stories point at the fictional trait of the sex and gender categories, to the extent to which any sex (biologically differentiated body) is an empty body if it lacks a gender that culturally gives meaning to it. Thus, if sex and gender are not natural, we propose a subversion, as the characters of the narratives do, to some extent, adopting performativity that exceeds binary boundaries, in the pursuit of freeing the body and its potentialities.

KEYWORDS: Clarice Lispector; Literature; Female body; Sexuality; Eroticism.

\footnotetext{
1 Mestre em Literatura Comparada pelo Programa de Pós-Graduação em Estudos da Linguagem, da Universidade Federal do Rio Grande do Norte (2018). Possui experiência na área de Letras, com ênfase em Literatura Comparada, atuando, principalmente, nos seguintes temas: gênero, identidade, literatura, escrita feminina e conto. E-mail: anapcomissario@gmail.com

2 Doutora em Letras. Professora Associada do Departamento de Línguas e Literaturas Estrangeiras Modernas na UFRN, atuando no Curso de Letras-Inglês e no Programa de Pós-graduação em Estudos da Linguagem na mesma universidade. E-mail: rosanne.bezerra@cchla.ufrn.br
} 


\section{Criação \&}

\section{Um breve passeio pela A Via Crucis do Corpo}

"E era assunto perigoso", "Fiquei chocada com a realidade", "Se há indecências na história a culpa não é minha”, "(...) este é um mundo-cão": essas são as impressões da própria Clarice Lispector no que concerne a sua coletânea de contos $A$ via crucis do corpo, publicada pela primeira vez em $1974^{3}$. O título do livro já nos adianta o que virá: o embate entre o sagrado ( $v i a$ crucis $^{4}$ ) e o profano (do corpo). Nos contos dessa coletânea, os leitores são compelidos a entrar em contato com uma das pulsões mais primitivas do ser humano: o desejo sexual que, milenarmente, devido principalmente à moral judaicocristã, foi recalcado por nós, por concebê-lo como sujo e pecaminoso. Tal desejo torna-se mais condenado se associado à mulher: a esta cabia a castidade. Em $A$ via crucis do corpo, essa pureza coloca-se em questão: as personagens femininas trazem à superfície o desejo interditado e suscitam desconforto nos leitores mais desprevenidos.

$O$ corpo feminino circunscrito às micronarrativas de $A$ via crucis do corpo ora assume suas pulsões sexuais e as vivencia, ora nega-as. A representação nesses contos não só da condição feminina, mas também de outros sujeitos historicamente silenciados na sociedade, permite-nos pensar que essa escritora, atenta aos sinais, mais uma vez soube captar o real e refratá-lo em seu universo ficcional, pois, não nos esqueçamos que, em 1974, o controle dos corpos ganhou contornos até mais violentos com a Ditadura Militar. Em contrapartida, os movimentos de resistência, dentre eles o feminismo, também se fortaleceram na luta pela liberdade dos corpos.

Em linhas gerais, nessa coletânea de contos, Clarice Lispector explora uma outra forma de narrar, abandonando, por assim dizer, o fluxo de consciência que a consolidou como escritora e não se importando com a opinião dos críticos. Lispector envereda-se por outras escolhas estéticas, renunciando à escrita metafórica e metafísica, em troca da espontaneidade formal e da abordagem de temas, como a sexualidade humana, nunca antes abordados de forma tão explícita por ela. Para a biógrafa de Lispector, Nadia Gotlib (2013, p. 522), A via crucis do corpo, de fato, "aborda o erótico implacável, misturando duas atitudes que mutuamente se complementam: um modo excessivamente direto de contar; e um humor que, sempre envolvendo o grotesco, por vezes chega a assumir um tom escrachado". E o corpo se presentifica nos contos criando uma unidade narrativa que nos permite lê-los comparativamente, funcionando como espelhos uns dos outros. Com efeito, um conto, pela aproximação do discurso ou, ao contrário, pelo distanciamento, auxilia-nos na extração das camadas interpretativas do outro conto, atuando como complementares, tal como percebemos em Ele me bebeu e Praça mauá.

Se, por um lado, o corpo é matéria física, por outro, configura-se dentro das esferas de poder como um corpo-linguagem que emite marcas identitárias. Lugar de individuação, mas também da diferença, os corpos femininos e masculinos são marcados e demarcados por símbolos sociais e culturais:

\footnotetext{
${ }^{3}$ Declarações de Clarice Lispector no primeiro texto do livro intitulado "Explicação" no qual a escritora tenta explicar a gênese da obra.

${ }^{4}$ Via-sacra é o percurso feito por Jesus carregando a sua cruz, rumo à crucificação. (LUCCHESI, 1991)
} 


\section{$29 \cos _{\text {Criticaão \& }}^{\text {Cria }}$}

o corpo não é um universo independente, fechado em si mesmo, à imagem do modelo anatômico, dos códigos de saber-viver ou do modelo mecanicista. O homem bem em carne (no sentido simbólico), é um campo de força em poder de ação sobre o mundo, e sempre a ponto de ser influenciado por ele. (BRETON, 2011, p. 50)

O corpo masculino, feminino, cis, trans, branco, negro, magro, gordo, saudável, doente, jovem e velho. Hierárquica e dicotomicamente, a sociedade construiu o mundo e os seres que nele habita e, como consequência, instituiu o modelo. Em oposição a este, a alteridade, o desvio da norma. Nesses pares de adjetivos atribuídos ao corpo, já sabemos quem configura como a alteridade. E o corpo-desvio tenta sobreviver aos percalços de sua interdita existência e prosseguir pela via crucis até o seu implacável destino: a sua crucificação.

A censura ao corpo é tão mais prescrita se ele se distancia da norma, pois oferece perigo. Assim, os corpos-desvios são controlados incessantemente pelas instâncias de poder. O corpo feminino (corpo-desvio) ocupa um lugar central que, assim regulado, opera na manutenção da ordem social. Interditadas as potencialidades do corpo, a manifestação de mulheridades dá lugar a uma única forma de mulheridade legítima: a mulher branca, heterossexual, cisgênera, jovem, magra e saudável. Essa constatação parece ficar mais evidente quando nos propomos a olhar para os personagens Aurélia Nascimento e Serjoca, personagens do conto "Ele me bebeu", e Carla/Luísa e Moleirão/Celsinho, personagens do conto "Mas vai chover".

Convém destacarmos que a escolha pela crítica literária feminista se justifica em virtude de ela nos oferecer conceitos operatórios, tais como gênero, falocentrismo, patriarcalismo, alteridade, desconstrução, entre outros, que nos auxiliam "no sentido de desconstruir a oposição homem/mulher e as demais oposições associadas a esta, numa espécie de versão do pós-estruturalismo" (ZOLIN, 2009, p. 218), propondo uma leitura que vai além do contexto da obra, de sua estrutura e economia, mas ao mesmo tempo abarca todas essas questões, pois uma escrita marcada pela diferença de gênero nos obriga a olhar para esses elementos. A recorrência de uma escrita biográfica e confessional, por exemplo, nas narrativas de autoria feminina comprova como a tessitura do texto literário também resulta das relações de gênero. A escritora-narradora costura um texto híbrido, no qual gêneros textuais, como diários e cartas, auxiliam na "conficção" 5 de sua condição feminina. Com efeito, a escrita literária feminina é antes uma escrita do seu corpo tímido, censurado, que encontra no texto um espaço de transgressão.

\footnotetext{
${ }^{5}$ Ivo Lucchesi, responsável pela apresentação da coletânea de contos A via crucis do corpo (1991) utiliza esse termo para ressaltar a inventividade de Clarice Lispector que, em um jogo poético com o leitor, apresenta-nos quatorze textos que passeiam pela confissão e ficção ao mesmo tempo.
} 


\section{Criaçãa \&}

\section{"Ele me bebeu": a (re)descoberta de si, por Aurélia Nascimento}

Narrado em terceira pessoa por um narrador aparentemente comprometido com o relato de uma história de modo objetivo e distanciado, o conto assim inicia-se: "É. Aconteceu mesmo" (LISPECTOR, 1991, p. 59). O suspense está instaurado e os personagens começarão a tomar "corpo" sob a perspectiva de um narrador que se propõe onisciente.

O primeiro a ser apresentado é Serjoca, descrito como "bonito", "magro e alto" cuja profissão era "maquilador de mulheres", embora, nas palavras do narrador, não quisesse as mulheres como objeto erótico, mas sim os homens. $E$ em meio às representações binárias de gênero (homem/mulher) e sexualidade (heterossexual/homossexual) imperantes na sociedade, Serjoca configurava-se como o desvio da norma e como sujeito abjeto que Butler (2003), à luz das ideias da crítica feminista Julia Kristeva, descreve como sendo imprescindível para "construir o sujeito singular por exclusão" e que Louro (2001, p. 548), conforme a perspectiva desconstrucionista de Jacques Derrida, aponta como sendo parte constitutiva da lógica dicotômica da sociedade, reiterada exaustivamente:

a lógica ocidental opera, tradicionalmente, através de binarismos: este é um pensamento que elege e fixa como fundante ou como central uma ideia, uma entidade ou um sujeito, determinando, a partir desse lugar, a posição do "outro", o seu oposto subordinado. O termo inicial é compreendido sempre como superior, enquanto que o outro é o seu derivado, inferior.

A noção de abjeto remete ao que é estranho ao corpo, que "foi expelido do corpo, descartado como excremento, tornado literalmente 'Outro' (BUTLER, 2003, 190). O corpo estranho, o "outro", gera repulsa pela transgressão da norma de um ideal de sujeito que, para exemplificar, no caso do velho, é o jovem, no caso do gordo, é o magro, e, no tocante ao conto "Ele me bebeu", é a mulher e o homem heterossexuais representados por Aurélia e Affonso. Serjoca (homem, maquiador de mulheres e homossexual), portanto, desnuda o caráter instável, contingente e questionável que há na instituição de uma correspondência dita como natural entre sexo (homem/mulher), gênero (masculino/feminino) que, por sua vez, geraria uma prática sexual e um desejo evidentemente heterossexuais. Nas palavras de Butler (2003, p. 39), essa "heterossexualização do desejo requer e institui a produção de oposições discriminadas e assimétricas entre 'feminino' e 'masculino', em que estes são compreendidos como atributos expressivos de 'macho' e de 'fêmea'. Como no caso de Aurélia Nascimento que é uma mulher (sexo) em consonância com seu gênero (feminino) e, em razão disso, adota a prática heterossexual como manifestação do desejo.

A caracterização de Aurélia corrobora com essa leitura. Aurélia era uma mulher, em termos biológicos (sexo), que correspondia ao que se esperava de uma mulher 


\section{Criaçäo \&}

(gênero). Preocupava-se com a aparência ("ela se vestia bem, era caprichada" ${ }^{\text {) }}$ e, para exaltar a sua beleza, recorria ao amigo Serjoca para fazer uma maquiagem que ressaltasse os traços de seu rosto. Não obstante, no afã de representar um padrão de beleza feminina cultuado pela sociedade, ela "usava peruca e cílios postiços" para parecer loira, além de "lentes de contato e seios postiços", pois considerava os seus seios pequenos.

A imagem do corpo de Aurélia calcada no exagero ("dentes grandes", "seios postiços", "sua boca era um botão de vermelha rosa", etc.) evidencia o caráter grotesco do conto, cujo narrador se incumbiu à tarefa de narrar com imparcialidade e objetividade (realismo). No entanto, como aponta Reguera, o realismo de "Ele me bebeu" é um realismo simulado:

A caracterização das personagens torna-se exemplar do papel que o narrador em terceira pessoa assume, ao se colocar como responsável pela condução do narrar: mesmo simulando um aparente distanciamento, caracteriza Aurélia como uma mulher "postiça", mascarada (2006, p. 223).

Assim, o olhar do narrador, ao contrário de imparcial e objetivo, é irônico e crítico em relação aos personagens e "destina seu discurso e, assim, as personagens, a um espaço híbrido e ambivalente: da simulação (parecer e não-ser) e da dissimulação (ser e não-parecer)" (REGUERA, 2006, p. 223). Vale ressaltarmos que o narrador não só em "Ele me bebeu", mas em diversos contos de $A$ via crucis do corpo, atua na economia narrativa como um personagem que, intencional e (dis)simuladamente, intromete-se nas histórias tecendo opiniões e comentários, colocando em questão o que é real e ficcional, o que é mentira e verdade.

E com aparente imparcialidade é caracterizado o terceiro personagem desse triângulo erótico:

Perto deles estava Affonso Carvalho. Industrial de metalurgia. Esperava o seu Mercedes com chofer. Fazia calor, o carro era refrigerado, tinha telefone e geladeira. Affonso fizera quarenta anos no dia anterior. (LISPECTOR, 1991, p. 60)

Affonso surge oportunamente em uma ocasião de desespero e impaciência de Aurélia e Serjoca que esperavam a cerca de uma hora um táxi na cidade do Rio de Janeiro, próximo ao Copacabana Palace:

Viu a impaciência de Aurélia que batia com os pés na calçada. Interessante essa mulher, pensou Affonso. E quer carro. Dirigiu-se a ela:

- A senhorita está achando dificuldade de condução?

- Estou aqui desde as seis horas e nada de um táxi passar e nos pegar! Já não aguento mais.

${ }^{6}$ LISPECTOR, 1991, p. 59. 


\section{Criaçäo \&}

- Meu chofer vem daqui a pouco, disse Affonso. Posso levá-los a alguma parte?

- Eu lhe agradeceria muito, inclusive porque estou com dor no pé.

Mas não disse que tinha calos. Escondeu o defeito. Estava maquiladíssima e olhou com desejo o homem. Serjoca muito calado.

Afinal veio o chofer, desceu, abriu a porta do carro. Entraram os três. Ela na frente, ao lado do chofer, os dois atrás. Tirou discretamente o sapato e suspirou de alívio (LISPECTOR, 1991, p. 60)

A caraterização da cena conduz ao leitor à suposição da imediata atração entre Affonso e Aurélia: "Aurélia cada vez mais acesa pela cara máscula de Affonso" (LISPECTOR, 1991, p. 61). Affonso, assim como a protagonista, incorpora os atributos físicos de um típico homem heterossexual (norma), em contraposição, como constatamos, à Serjoca (desvio). A norma e o desvio também atingem os próprios nomes dos personagens. O homossexual maquiador de mulheres não é nomeado de Sérgio, mas sim Serjoca; semelhante a adjetivos, como boboca e dorminhoca, que servem para intensificar jocosamente alguma característica, qualidade ou defeito de um indivíduo. Assim, uma pessoa alcunhada de dorminhoca, por exemplo, não é aquela que gosta de dormir, mas sim aquela que gosta de dormir demasiadamente.

Nessa perspectiva, Serjoca conota excesso, exagero, o corpo estranho, em oposição a Affonso Carvalho, homem heterossexual representado pela formalidade de um nome e sobrenome, os quais induzem ao leitor à seriedade, enquanto Serjoca à comicidade. Assim, Reguera (2006, p. 201) acerta ao afirmar que o livro $A$ via crucis do corpo é "um projeto literário pautado pela paródia, pelo ludismo e pela ironia". O cômico não gratuitamente, mas crítico, de modo a elucidar as contradições do ser humano e de seu corpo, que contrariam as normas sociais e transbordam as fronteiras de gênero, sexualidade e desejo.

Essas contradições ficarão mais evidentes após a interação entre os três personagens. A aparente atração entre Affonso e Aurélia compele os três personagens a uma boate à procura de bebida:

Então foram para a boate, a essa hora quase vazia. E conversaram. Affonso falou de metalurgia. Os outros dois não entendiam nada. Mas fingiam entender. Era tedioso. Mas Affonso estava entusiasmado e, embaixo da mesa, encostou o pé no pé de Aurélia. Justo o pé que tinha calo. Ela correspondeu, excitada. Aí Affonso disse:

- E se fôssemos jantar na minha casa? Tenho hoje escargots e frango com trufas. Que tal?

- Estou esfaimada.

E Serjoca mudo. Estava também aceso por Affonso. (LISPECTOR, 1991, p. 61)

A cena erótica ("encostou o pé no pé de Aurélia") entre Affonso e Aurélia, que descamba para o grotesco e, por consequência, para o cômico ("justo o pé que tinha 


\section{Criaçäo \&}

calo"), evidencia um fato que já vinha sendo costurado pelo narrador no decorrer da tessitura ficcional de "Ele me bebeu": Serjoca também se sentia atraído por Affonso. Descrito como "muito calado", "mudo", durante o encontro entre os três personagens, a postura do rapaz sinalizava um estado de inveja da amiga Aurélia, já que o seu objeto de desejo se sentiu atraído, de imediato, por ela.

Ele passa a ver a protagonista como uma rival, contrariando a correspondência entre o seu sexo e gênero, e encarnando o gênero oposto (feminino), pois, na perspectiva social, a inveja e a rivalidade são consideradas características femininas, como aponta Paz (1994, p. 105): entre as mulheres "são frequentes a intriga, as invejas, as fofocas, os ciúmes e as pequenas maldades. Tudo isso se deve, quase seguramente, não a uma incapacidade inata das mulheres e sim a sua situação social".

Mas a posição de Serjoca dentro do triângulo amoroso se modificará durante a interação entre os personagens na casa de Affonso. De coadjuvante o personagem, junto ao metalúrgico, tornar-se-á protagonista da encenação erótica:

E foram para a sala. Aí Serjoca se animou. E começou a falar que não acabava mais. Lançava olhos lânguidos para o industrial. Este ficou espantado com a eloquência do rapaz bonito. No dia seguinte telefonaria para Aurélia para Ihe dizer: o Serjoca é amor de pessoa. (LISPECTOR, 1991, p. 62)

À luz da simulação (parecer e não-ser) e da dissimulação (ser e não-parecer) bem arquitetada na ação e caracterização dos personagens, o narrador conduz a/o leitor/a ao imprevisível, subvertendo toda a lógica de verossimilhança que até então havia sido construída. Affonso desestabiliza a relação de "coerência e continuidade entre sexo, gênero, prática sexual e desejo" (BUTLER, 2003, p. 38) que vinha sendo encenada e compele o leitor a olhar para o desejo para além de noções identitárias dicotômicas que castram as possibilidades de experiência do corpo, pois este não se conforma aos esquemas binários.

Affonso é um sujeito queer, pois rompe com as categorias binárias e se coloca "contra a normalização - venha ela de onde vier" (LOURO, 2001, p. 546). Situa-se na fronteira ou sugere o seu desmonte. À luz das identidades (heterossexual/homossexual), confortabiliza-se na pós-identidade, contrariando uma perspectiva estruturalista e essencialista de sujeito (identidade) e assumindo uma sexualidade em processo, em devir. Com efeito, se Affonso transcende as fronteiras de gênero e sexualidade é porque elas são meramente discursivas e ficcionais (inventadas), responsáveis pela produção de verdades (regime de verdade) sobre o prazer (FOUCAULT, 2015) cuja intenção é regular e controlar as práticas corporais.

Contestando uma suposta essência do sujeito (identidade heterossexual/homossexual), o metalúrgico se constrói na ação, na interação, e nos revela que a noção de identidade de gênero e sexualidade é uma invenção, reiterada por meio de atos, gestos, símbolos que nos dão a sensação de que existe algo natural, substancial, anterior ao discurso. As roupas que nós, homens e mulheres, escolhemos, o 


\section{Criaçäo \&}

modo como nos comportamos, denunciam essa representação de nós mesmos.

Nesse sentido, aproximamo-nos de Butler quando propõe o termo "performatividade" de gênero como a estilização dos corpos no âmbito da sociedade que cristaliza uma ideia de masculinidade e feminilidade. Assim, nós somos atos e não fatos. Affonso, ao olhar eroticamente Serjoca ("ele ficou espantado com a eloquência do rapaz bonito"), reinventa a sua existência e subverte a lógica binária de gênero e sexualidade, revelando a realidade discursiva e ficcional dessas dicotomias.

Essa estilização do corpo (performatividade), ou encenação de si, também pode ser percebida claramente na caracterização de Aurélia como uma mulher "postiça". A protagonista se constitui na tensão do parecer/não-ser, sempre representando a si mesma e escondendo as suas supostas fissuras ("Mas não disse que tinha calos. Escondeu o defeito", "tirou discretamente o sapato e suspirou de alívio"). Aurélia se "monta" de mulher por meio de atos performativos que sugerem novamente a realidade ficcional do ser "mulher", "homem", "heterossexual", "homossexual" e, quando não se traveste de si, é confrontada com outros "eus" que se escondiam nas camadas superficiais do seu ser mulher. Isso fica evidente quando os três personagens resolvem se encontrar novamente:

Mas antes de se encontrarem, Aurélia telefonou para Serjoca: precisava de maquilagem urgente. Ele foi à sua casa.

Então, enquanto era maquilada, pensou: Serjoca está me tirando o rosto.

A impressão era a de que ele apagava os seus traços: vazia, uma cara carne só de carne. Carne morena.

Sentiu mal-estar. Pediu licença e foi ao banheiro para se olhar no espelho. Era isso mesmo que ela imaginara: Serjoca tinha anulado o seu rosto. Mesmo os ossos - e tinha uma ossatura espetacular - mesmo os ossos tinham desaparecido. Ele está me bebendo, pensou, ele vai me destruir. $E$ é por causa do Affonso.

Voltou sem graça. No restaurante quase não falou. Affonso falava mais com Serjoca, mal olhava para Aurélia: estava interessado no rapaz. (LISPECTOR, 1991, p. 63)

Ao anular os traços de Aurélia, Serjoca susta a performatividade de gênero da protagonista desencadeando-Ihe "epifanicamente" outras realidades de si que ela não reconhecia como sendo inerente ao seu ser-mulher:

Chegou em casa, tomou um banho de imersão com espuma, ficou pensando: daqui a pouco ele me tira o corpo também. O que fazer para recuperar o que fora seu? A sua individualidade? (...) Foi ao espelho. Olhou-se profundamente. Mas ela não era mais nada. (LISPECTOR, 1991, p. 63)

O corpo esvaziado (sexo) das inscrições culturais que Ihe significam (gênero) nada tem a dizer sobre o sujeito, suscitando-lhe o perigo de não se adequar a um dos lados da fronteira (homem/mulher): "uma pessoa é o seu gênero na medida em que não é 


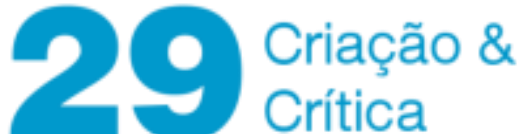

o outro gênero, formulação que pressupõe e impõe a restrição do gênero dentro desse par binário" (BUTLER, 2003, p. 45). Assim, o desespero de Aurélia ("Mas ela não era mais nada") é antes a tomada de consciência de que o seu "eu" (identidade) é um ente inventado, por meio de atos performativos, que gera a impressão de uma suposta natureza feminina e masculina:

\section{E realmente aconteceu.}

No espelho viu enfim um rosto humano, triste, delicado. Ela era Aurélia Nascimento. Acabara de nascer. Nas-ci-men-to. (LISPECTOR, 1991, p. 63)

Sem a estilização de gênero, a protagonista é apenas um corpo humano, que agora pode romper com os esquemas binários, admitir e assumir seu corpo como processo, um devir, uma matéria contingente e não conformativa de normatização. Sujeitar-se aos contornos é limitar suas possibilidades e potencialidades, e, no caso de Aurélia, suas mulheridades.

\section{"Praça Mauá": Quem é mulher de verdade?}

Uma relação de tensão e ambiguidade (ser/parecer) também perpassa a economia narrativa do conto "Praça Mauá". A (dis)simulação é estabelecida, sobretudo, na caracterização dos personagens por meio da voz de um narrador irônico e crítico. Personagens dúbias cujas performatividades são incorporadas e desincorporadas na assunção de nomes diferentes para cada representação de si. Luísa adotava o "nome de guerra" Carla, nos momentos em que trabalhava no cabaré "Erótica", localizado na Praça Mauá, e Celsinho, que também trabalhava no cabaré, adotava o "nome de guerra" Moleirão.

Em contraste a Aurélia Nascimento, Carla/Luísa se definia pelo comedimento, não pelo exagero:

Carla era linda. Tinha dentes miúdos e cintura fininha. Era toda frágil. Quase não tinha seios mas tinha quadris bem torneados. Levava uma hora para se maquilar: depois parecia uma boneca de louça. Tinha trinta anos mas parecia muito menos. (LISPECTOR, 1991, p. 81)

E Celsinho/Moleirão, como "um homem que não era homem":

Nos seus momentos de infelicidade socorria-se de Celsinho, um homem que não era homem. Entendiam-se bem. Ela Ihe contava suas amarguras, queixava-se de Joaquim, queixava-se da inflação. Celsinho, um travesti de sucesso, ouvia tudo e aconselhava. Não eram rivais. Cada um tinha o seu parceiro. (LISPECTOR, 1991, p. 82) 


\section{Criaçäo \&}

No entanto, ao contrário de Serjoca (“Ele me bebeu”), Celsinho/Moleirão era um travesti, o que envolve outros processos de subjetivação e atos performativos. O termo 'travesti' se origina do vocábulo verbal 'transvestir' cuja acepção que adotamos neste trabalho consiste em "vestir roupas do sexo oposto (ou cross-dress, em inglês)" (KULICK, 2008, p. 21). No entanto, conforme destaca Kulick (2008, p. 21),

as travestis não se caracterizam apenas por usar roupas de mulher. (...) elas adotam nomes femininos, roupas femininas, penteados e maquiagem femininos, pronomes de tratamento femininos, além de consumirem grande quantidade de hormônios femininos e pagarem para que outras travestis injetem até vinte litros de silicone industrial em seus corpos, como o objetivo de adquirir aparência física feminina, com seios, quadris largos, coxas grossas e, o mais importante, bundas grandes.

Apesar da personagem travesti de "Praça Mauá" não adotar um nome feminino, a sua caracterização corrobora com a definição acima: "Não dançava. Mas usava batom e cílios postiços", "tinha quadris largos e, de tanto tomar hormônio, adquirira um facsímile de seios" (LISPECTOR, 1991, p. 83). Interessante notarmos que, ao contrário dos transexuais, as travestis não reivindicam a identidade de gênero feminina, como constata Kulick:

a combinação singular de atributos físicos femininos e subjetividade homossexual masculina é o que faz as travestis serem quase únicas no mundo. Embora existam muitas culturas em que indivíduos, em graus variados e por diferentes meios, cruzam as fronteiras de gênero, travestis parecem ser um dos poucos casos em que se altera o corpo irrevogavelmente para que este se assemelhe ao do sexo oposto, sem contudo reivindicar a subjetividade própria ao sexo oposto (2003, p. 22).

Assim, mesmo mediante um conjunto de práticas corporais que almejam simular o gênero oposto, as travestis se consideram homens que desejam outros homens (homossexual), e muitas até assumem o gênero masculino durante o dia, por meio de atos performativos que imitam o ideal de homem, como usar roupas consideradas masculinas, como é o caso de Moleirão que se transforma em Celsinho quando deixa o cabaré "Erótica". Vale ressaltarmos, no entanto, que a tendência é que o travesti, de modo gradativo, passe a usar roupas e acessórios permanentes atribuídos à mulher (KULICK, 2008, p. 65).

O travesti, ao inventar uma feminilidade que, do ponto de vista biológico, não the condiz, desmantela a relação lógica entre sexo e gênero, desafiando-nos a pensar até que ponto essa lógica seria realmente natural (biológica). Assim,

o travesti também revela a distinção dos aspectos da experiência do gênero que são falsamente naturalizados como uma unidade através da ficção reguladora da coerência heterossexual (BUTLER, 2003, p. 196). 


\section{Criaçäo \&}

No entanto, se por um lado o travesti desestabiliza a noção de sexo/gênero, assumindo atos performativos de seu sexo oposto, por outro, também se circunscreve em consonância com essa noção, ao reiterar que um homem, "realmente homem" (heterossexual), só se atrai por mulheres, por isso a necessidade de se assemelhar à mulher. Kulick ratifica esse pensamento quando, em seu estudo sobre as travestis, coloca que "não há nada de estranho ou confuso com as percepções de gênero das travestis, muito pelo contrário. Elas traduzem seu desejo por homens de uma forma culturalmente adequada - ou seja, como um desejo heterossexual" (2008, p. 244).

Todavia, mesmo reiterando essas noções, a figura do travesti revela-se importante para a comprovação de que "homem" e "mulher" são categorias inventadas com fins a regular os corpos e suas potencialidades. Ela embaralha o jogo binário, já que não se sente psicologicamente uma mulher (transexual), traveste-se de mulher ideal, e, ao mesmo tempo, identifica-se como um homem homossexual. Logicamente, concebendo o gênero pelo viés da performatividade, não podemos e nem pretendemos homogeneizar as travestis, mas tão somente tentar mostrar como "o gênero é uma identidade tenuemente constituída no tempo, instituído num espaço externo por meio de uma repetição estilizada de atos" (BUTLER, 2003, p. 200).

Em suma, o travesti se constitui em razão de seu desejo homoerótico e se travestir de mulher faz parte do seu entendimento do que vem a ser homem e mulher "de verdade". Isso é o que constatou Kulick ao perguntar às travestis: "Quando você descobriu que era diferente dos outros garotos?', elas de imediato mencionavam a atração por homens e sua vontade íntima de parecer atraentes para eles" (2008, p. 68). Assim, para o travesti, "um indivíduo do sexo masculino é um homem 'porque' deseja uma mulher; uma travesti pode 'sentir-se como uma mulher' na medida em que ela deseja um homem e é por ele desejada" (KULICK, 2008, p. 140).

Mas Moleirão vai além de só travestir-se de mulher, pois, longe do "Erótica" na identidade de Celsinho, incorporava os papéis imputados à mulher, supostamente inerentes à natureza feminina. Parecia ter "vocação" para maternidade, como podemos notar neste fragmento:

Celsinho tinha adotado uma meninazinha de quatro anos. Era-Ihe uma verdadeira mãe. Dormia pouco para cuidar da menina. A esta não faltava nada: tinha tudo do bom e do melhor. E uma babá portuguesa. Aos domingos Celsinho levava Claretinha ao Jardim Zoológico, na Quinta da Boa Vista. E ambos comiam pipocas. E davam de comida aos macacos. Claretinha tinha medo dos elefantes. Perguntava:

- Por que é que eles têm nariz tão grande?

Celsinho então contava uma história fantástica onde entravam fadas más e fadas boas. Ou então levava-a ao circo. E chupavam balas barulhentas, os dois. Celsinho queria para Claretinha um futuro brilhante: casamento com homem de fortuna, filhos, jóias. (LISPECTOR, 1991, p. 83-84) 


\section{Criaçäo \&}

O amor incondicional e o cuidado de Celsinho com a filha corroboram com o argumento do narrador de que ele era "um homem que não era homem" (noção tradicional de gênero e sexualidade). $E$ isso fica mais notório quando o narrador, imediatamente à caracterização de Celsinho, contrasta com Carla:

Carla tinha um gato siamês que a olhava com olhos azuis e duros. Mas Carla mal tinha tempo de cuidar do bicho: ora estava dormindo, ora dançando, ora fazendo compras. O gato se chamava Leléu. $E$ tomava leite com sua linguinha vermelha e fina. Joaquim mal via Luísa. Recusava-se a chamá-la de Carla. Joaquim era gordo e baixo, descendente de italianos. Quem Ihe tinha dado o nome de Joaquim fora uma vizinha portuguesa. Chama-se Joaquim Fioriti. Fioriti? de flor não tinha nada. (LISPECTOR, 1991, p. 84)

Opostamente a Celsinho, Carla representava a subversão do ideal de mulher. Negligente com o seu animal de estimação ("que dirá com um filho?" é o que o narrador parece nos sugerir), o narrador constrói uma cena grotesca ("linguinha vermelha e fina", "gordo e baixo") em um tom crítico que se traduz nos seus comentários sobre os personagens.

Essa cena em oposição à anterior nos obriga a pensar fora dos esquemas binários de representação de gênero, pois a protagonista subverte a noção de mulher e a personagem travesti subverte a de homem, ao passo que este também reitera por meio de seus atos performativos a percepção de mulher que Carla havia transgredido. A projeção de Celsinho em Claretinha ("Celsinho queria para Claretinha um futuro brilhante: casamento com homem de fortuna, filhos, jóias") exterioriza a mulher que ele incorpora: a mulher operacionalizada como normal que reflete a relação de continuidade entre sexo, gênero, sexualidade e desejo (BUTLER, 2003).

A concepção de mulher da personagem travesti se manifestará mais explicitamente em uma cena no cabaré, após Carla ter sido chamada para dançar por um homem másculo que Moleirão (nome adotado no cabaré) desejava. O estado de Moleirão era de inveja ("E roeu-se de inveja. Era vingativo") e raiva:

Quando a dança acabou e Carla voltou a sentar-se junto de Moleirão, este mal se continha de raiva. E Carla inocente. Não tinha culpa de ser atraente. $\mathrm{E} O$ homem grandalhão bem que Ihe agradara. Disse para Celsinho:

- Com este eu ia para a cama sem cobrar nada. (...)

Então Carla disse:

- É tão bom dançar com um homem de verdade. Celsinho pulou:

- Mas você não é mulher de verdade!

- Eu? Como é que não sou? Espantou-se a moça que nesta noite estava vestida de preto, um vestido longo e de mangas compridas, parecia uma

\footnotetext{
${ }^{7}$ LISPECTOR, 1991, p. 84.
} 


\section{Criaçäo \&}

freira. Fazia isso de propósito para excitar os homens que queriam mulher pura.

- Você, vociferou Celsinho, não é mulher coisa alguma! Nem ao menos sabe estalar um ovo! E eu sei! Eu sei! Eu sei! (LISPECTOR, 1991, p. 85)

A assertiva de Moleirão ("Mas você não é mulher de verdade!") funciona como um desfecho coerente e coeso, considerando a construção dos personagens que o narrador vinha fazendo. Os atos performativos da personagem travesti a coloca na posição de "mulher de verdade" em detrimento da própria "mulher de verdade" do conto na acepção tradicional de mulher.

Todavia, a indignação de Celsinho é ambígua, pois embora, como já mencionamos, a travesti não se considere ou pleiteie o status de mulher, ao mesmo tempo, nas suas concepções de gênero, sabe que nunca será anatomicamente uma mulher, o que lhe causa inveja da protagonista. É o que constata Kulick quando afirma que a "característica anatômica que as travestis consideram horrível é a mesma que elas reconhecem - torna as mulheres atrativas para os homens" (2008, p. 205). Assim, para as travestis, se um homem é um "homem de verdade" em função de seu desejo por uma mulher, no sentido anatômico, analogicamente, uma mulher teria o status de "mulher de verdade" pelo mesmo motivo.

Essa analogia se torna problemática no conto, porque, mesmo possuindo genitália atribuída ao sexo feminino, Carla não é considerada por Moleirão uma verdadeira mulher em razão de não incorporar os papéis tidos como tipicamente femininos em sua performatividade de gênero, tais como cuidar de uma casa, de um filho, de um marido, ou fritar um ovo.

O corpo feminino da protagonista não se conforma à noção de mulher, adotando atos performativos que a subvertem, em consonância com o pensamento butleriano que defende a adoção de práticas discursivas e performativas que desestabilizem as normas sexuais calcadas no binarismo de gênero e na heterossexualidade compulsória. Sob esse viés, as nossas práticas são sempre ações que realizam o que nomeiam, sejam operando em favor da ordem estabelecida ou transgredindo-a. Caberia a nós tomarmos consciência disso, desestabilizando a linguagem bem como assumindo novas práticas que rompam com a percepção binária de mundo.

A noção de um discurso que inventa aquilo que nomeia fica mais evidente no contexto de uma ultrassonografia ou no momento do parto em que um médico ou uma enfermeira anuncia "É uma menina/menino!" e a partir dessa ocasião a nossa identidade de sexo é atribuída ${ }^{8}$. A esse ato discursivo, Butler denomina de "interpelação" que serve "num sentido especificamente teórico para descrever como as posições de sujeito são conferidas e assumidas através do ato pelo qual a pessoa é chamada (no sentido de "atrair a atenção")" (SALIH, 2012, p. 109). Portanto, a célebre frase de Beauvoir poderia ser reescrita: "não se nasce mulher, se é chamada de mulher" (SALIH, 2012, p. 109).

Para Butler, "a linguagem não nomeia simplesmente um corpo preexistente: no

\footnotetext{
${ }^{8}$ Sobre isso, Salih, à luz de Butler, coloca contundentemente que "falar em termos de "atribuição" de sexo já significa supor que ele não é "natural" ou dado (...)".
} 


\section{Criaçäo \&}

ato de nomeação ela constitui o corpo". Tornamo-nos mulheres e homens por meio das interpelações cotidianas que demarcam as fronteiras e consolidam reiteradamente as normas, inventando corpos conformados e educados. Moleirão e Carla fazem uso dessa interpelação. Esta sugere um "homem de verdade" e aquele insinua uma "mulher de verdade".

A interpelação de Moleirão produz uma nova Carla:

Carla virou Luísa. Branca, perplexa. Tinha sido atingida na sua feminilidade mais íntima. Perplexa, olhando para Celsinho que estava com cara de megera. Carla não disse uma palavra. Ergueu-se, esmagou o cigarro no cinzeiro e, sem explicar a ninguém, largando a festa no seu auge, foi embora.

Ficou de pé, de preto, na Praça Mauá, às três horas da madrugada. Como a mais vagabunda das prostitutas. Solitária. Sem remédio. Era verdade: não sabia fritar um ovo. E Celsinho era mais mulher que ela.

A praça estava às escuras. E Luísa respirou profundamente. Olhava os postes. A praça vazia.

E no céu as estrelas. (LISPECTOR, 1991, p. 86)

A ambivalência imbricada no vocábulo "branca" representa pertinentemente o estado de incredulidade da protagonista. Estava em um estado de palidez e também de clarificação epifânica. Aceitou a interpelação de Moleirão/Celsinho e se desqualificou enquanto mulher. Mas ela não percebeu que a acusação de Moleirão/Celsinho era despeito, em virtude de ter a consciência da impossibilidade de acesso à feminilidade da mesma maneira que um sujeito anatomicamente mulher": "as mulheres são vistas pelas travestis como quem tem acesso privilegiado à feminilidade" (KULICK, 2008, p. 207).

Em linhas gerais, o que notamos é que, assim como Aurélia "Nascimento" ("Ele me bebeu"), a personagem de "Praça Mauá" foi confrontada consigo mesma. Com a representação de si. Com a identidade construída e reiterada performativamente em suas práticas discursivas. Crucificada pela via crucis do outro, a protagonista será obrigada a juntar os fragmentos de sua representação e renascer. Quem sabe adotando um outro nome, constituindo-se como um outro que admite sua natureza contingente e que a "mulher é um termo em processo, um devir, um construir de que não se pode dizer com acerto que tenha uma origem ou um fim" (BUTLER, 2003, p. 58-59).

\section{Reiventando os corpos}

Entre a tensão da simulação (parecer e não-ser) e dissimulação (ser e nãoparecer), verificamos como se (des)constroem os corpos atravessados pelas marcas de gênero e sexualidade, desestabilizando concepções responsáveis pela demarcação de fronteiras entre os corpos. Desmontamos a coerência lógica entre sexo, gênero e desejo,

\footnotetext{
${ }^{9}$ Esperamos que até esse ponto já tenha ficado claro que não partilhamos das concepções de gênero e sexualidade do personagem Serginho/Moleirão.
} 


\section{Criaçäo \&}

por meio de personagens que não se enquadram nessas configurações, tais como Serjoca, Aurélia e Affonso do conto "Ele me bebeu" e Moleirão/Celsinho e Luísa/Carla do conto "Praça Mauá".

As representações que as personagens fazem de si mesmas apontam para o caráter ficcional das categorias sexo e gênero, na medida em que um sexo (corpo biologicamente diferenciado), sem o gênero que Ihe atribui culturalmente um significado, é um corpo vazio. Constatamos que os atos performativos de Aurélia ("Ele me bebeu") e de Moleirão/Celsinho ("Praça Mauá") que (dis)simulam uma ideia de mulher acabam por revelar que essas categorias (homem/mulher) não são naturais, como o discurso hegemônico tenta nos incutir, precisando ser reiteradas e fabricadas discursivamente nas práticas sociais. Assim, se não são naturais, propomos a sua subversão, como o faz até certo ponto os personagens supracitados, adotando performatividades que cruzem as fronteiras binárias em direção à libertação dos corpos e suas potencialidades.

Em suma, os contos aqui analisados transgridem as concepções identitárias tradicionais generificadas e sugerem discursivamente o não engessamento dos corpos em categorias de gênero e sexualidade, pois práticas corporais ultrapassam qualquer tentativa de imprimir uma identidade estável. Assim, a fluidez dessas categorias seria a única realidade possível para a complexidade humana. Desestabilizando a nossa percepção binária dos corpos, "Ele me bebeu" e "Praça mauá" desconstroem noções de gênero e sexualidade que serviram de base para nos ancorarmos no mundo social. Os discursos engendrados nas narrativas confluem-se com discussões teóricas recentes sobre gênero e sexualidade, comprovando como a literatura antecipa conceitos, transformando-se ela própria em uma teoria sobre a vida.

\section{Referências bibliográficas}

BUTLER, Judith. Problemas de gênero: feminismo e subversão da identidade. Tradução de Renato Aguiar. Rio de Janeiro: Civilização Brasileira, 2003.

FOUCAULT, Michel. História da Sexualidade 1: A vontade do saber. Trad. Maria Thereza da Costa Albuquerque e J.A. Guilhon Albuquerque. 2ª ed. São Paulo: Paz e Terra, 2015. GOTLIB, Nádia Batella. Clarice: uma vida que se conta. 7aㅡ ed. São Paulo: EDUSP, 2013. KULICK, Don. Travesti: prostituição, sexo, gênero e cultura no Brasil. Trad. Cesar Gordon. Rio de Janeiro: Editora Fiocruz, 2008.

BRETON, David le. Antropologia do corpo e modernidade. Trad. Fábio dos Santos Creder Lopes. Petrópolis: Vozes, 2011.

LISPECTOR, Clarice. A via crucis do corpo, 4 ed. Rio de Janeiro: Francisco Alves, 1991. LOURO, Guacira Lopes. Teoria Queer - Uma política pós-identitária para a educação. Estudos Feministas, Florianópolis, Ano 9, p. 541-553, 2ำ sem./2001. Disponível em: <https://www.scielo.br/pdf/ref/v9n2/8639.pdf>. Acesso em: 29 jun. 2020.

LUCCHESI, Ivo. "A paixão do Corpo entre os Fantasmas e as Fantasias do Desejo". In: LISPECTOR, Clarice. A via crucis do corpo, 4 ed. Rio de Janeiro: Francisco Alves, 1991, 


\section{$29^{\text {crancáco \& }}$}

p. 03-15.

PAZ, Octavio. A dupla chama - Amor e Erotismo. Trad. Wladyr Dupont. São Paulo: Siciliano, 1994.

REGUERA, Nilze Maria de Azevedo. Clarice Lispector e a encenação da escritura em A via crucis do corpo. São Paulo: Editora UNESP, 2006.

SALIH, Sara. Judith Butler e a Teoria Queer. Trad. Guacira Lopes Louro. Belo Horizonte: Autêntica Editora, 2012.

ZOLIN, Lúcia Osana. "Crítica feminista". In: BONNICl, Thomas; ZOLIN, Lúcia Osana(orgs.). Teoria Literária: Abordagens históricas e tendências contemporâneas. Maringá: Eduem, 2009, p. 217-242.

Lúcia Osana. "Literatura de autoria feminina". In: BONNICI, Thomas; ZOLIN, Lúcia Osana(orgs.). Teoria Literária: Abordagens históricas e tendências contemporâneas. Maringá: Eduem, 2009, p. 327-336.

Recebido em: 29/06/2020

Aceito em: 29/06/2020

Referência eletrônica: COMISSÁRIO, Ana Paula Pereira; ARAÚJO, Rosanne Bezerra. Quem é mulher de verdade? - corpo feminino e sexualidade em $A$ via crucis do corpo, de Clarice Lispector. Criação \& Crítica, n. 29, p., mai. 2021. Disponível em: <http://revistas.usp.br/criacaoecritica>. Acesso em: dd mmm. aaaa. 